\title{
CRÓNICA DE JURISPRUDENCIA 2006. DERECHO ECLESIÁSTICO ESPAÑOL*
}

\author{
JORGE OTADUY
}

\begin{abstract}
S U M A R I O
I • TRIbUnAl EUROPEO DE DEREChOS HUMANOS. II • TRIBUNAL CONSTITUCIONAL. III • TRIBUNAL SUPREMO. 1. Profesores de religión. 1.1. Carácter laboral de la relación. 1.2. Seguridad Social. 1.3. Experiencia docente. 2. Impuesto sobre bienes inmuebles. 3. Libertad de enseñanza. 4. Inscripción de bienes inmuebles. IV • AUDIENCIA NACIONAL. 1. Profesores de religión. 2. Exención del Impuesto sobre el Valor Añadido. 3. Seguridad Social. V • TRIBUNALES SUPERIORES DE JUSTICIA. 1. Libertad religiosa. 2. Régimen tributario. 2.1. Impuesto de Sociedades. 2.2. Impuestos reales. 2.3. Impuesto sobre el Valor Añadido. 2.4. Impuesto sobre bienes inmuebles. 2.5 Impuesto sobre el incremento del valor de los terrenos. 3. Profesores de religión. 3.1. Exclusión del ámbito del Convenio colectivo. 3.2. Experiencia docente. 3.3. Carácter laboral de la relación. 3.4. Horarios. 3.5. Indemnización por término de contrato. 3.6. Complemento salarial de antigüedad. 4. Cajas de Ahorros. 5. Libertad de enseñanza. 6. Días festivos. 7. Seguridad Social de clérigos y religiosos. 8. Matrimonio. VI • AUDIENCIAS PROVINCIALES. 1. Libertad religiosa. 2. Matrimonio. 3. Cementerios. 4. Responsabilidad civil subsidiaria. 5. Entidades eclesiásticas.
\end{abstract}

\section{TRIBUNAL EUROPEO DE DERECHOS HUMANOS}

Seis sentencias del Tribunal de Estrasburgo merecen ser destacadas en esta Crónica de 2006. En tres de ellas se invoca directamente el art. 9, sobre libertad religiosa, con declaración afirmativa a la denuncia de su violación en dos ocasiones. Ambas se refieren a la protección de la autonomía de las confesiones religiosas frente a injerencias estatales. En los últimos años — véase, por ejemplo, los casos Serif y Besarabia, entre otros— se está consolidando en esta ma-

* La numeración marginal corresponde al Repertorio de Jurisprudencia de ThomsonAranzadi. Téngase en cuenta que la abreviatura JUR se refiere a resoluciones no publicadas en los productos CD/DVD de Thomson-Aranzadi. Se encuentran solamente en Westlaw, el servicio de Internet de la editorial.

IUS CANONICUM, XLVII, N. 93, 2007, págs. 271-306 
teria una de las líneas más fecundas de la doctrina del Tribunal Europeo. El tercer caso se refiere a la dimensión individual de la libertad religiosa en el ámbito laboral, donde, necesariamente, los márgenes de reconocimiento de la autonomía personal son más estrechos como consecuencia de las específicas obligaciones asumidas por el trabajador.

El derecho a la vida privada, reconocido en el art. 8 del Convenio, es objeto principal de análisis en otras dos sentencias. Uno de los casos guarda relación con aspectos de la organización de la vida familiar y otro con el respeto de los difuntos.

Por último, se recoge un caso de libertad de expresión en materia religiosa. La doctrina del Tribunal Europeo en esta materia no es precisamente modélica. La perplejidad es notable cuando se comprueba, por ejemplo, la distinta manera de afrontar los casos de difamación relacionados con la religión cristiana y con la religión islámica (véase, en este sentido, la Sentencia de 13 de septiembre de 2005, en la Crónica de jurisprudencia publicada en esta misma Revista el año pasado).

- Sentencia del Tribunal Europeo de Derechos Humanos (Sección $1^{\underline{a}}$ ), de 5 de octubre de 2006 (TEDH 2006/54). Autonomía de las confesiones religiosas. Violación del art. 9

La Ley de Religiones de 1998 impuso la nueva inscripción de todas las organizaciones religiosas reconocidas en Rusia anteriormente. El rechazo de la nueva inscripción expondría a la organización religiosa a la amenaza de disolución por decisión judicial. El «Ejército de Salvación», que operaba legalmente en Rusia desde 1992, no obtuvo el nuevo reconocimiento por una supuesta interpretación arbitraria de los requisitos de la Ley de Religiones. La Sentencia del Tribunal Europeo, en la línea de las grandes decisiones protectoras de la autonomía de las confesiones - como Bessarabia y otros contra Moldavia, de 2001, por ejemplo- declara la violación del artículo 9. Una injerencia en el derecho de libertad religiosa solamente se justifica si es necesaria en una sociedad democrática. Las asociaciones religiosas son importantes para el correcto funcionamiento de la democracia. Las excepciones a la norma de la libertad de asociación deben ser estrictas y únicamente razones convincentes e imperiosas pueden justificar restricciones a esa libertad. El Gobierno no especificó los motivos concretos para denegar la nueva inscripción al demandante. No indicó ninguna justificación para la injerencia. 
- Sentencia del Tribunal Europeo de Derechos Humanos (Sección $1^{\underline{a}}$ ), de 13 de julio de 2006 (JUR 2006/204567). Autonomía de las confesiones religiosas. Violación del art. 9

Un ciudadano griego, elegido Mufti por su comunidad religiosa, fue condenado por el delito de usurpación de funciones de los agentes estatales o municipales después de que el Estado Griego nombrara otro Mufti y el primero continuara ejerciendo ciertas actividades y presentándose de acuerdo con la posición religiosa que ostentaba. El argumento del Gobierno era que la condena respondía a una conducta tipificada como delito y nada tenía que ver con las creencias religiosas del condenado. No es del mismo parecer el Tribunal Europeo, que declara la violación del artículo 9 del Convenio. Hace notar que los actos del demandante —el envío de mensajes de contenido religioso— no eran ejercicio de competencias judiciales o administrativas propias de los Muftis o de otros ministros de «religiones reconocidas» a cuya protección se refiere la norma penal. Por otra parte, no se apreciaba una particular presión social que justificara una intervención fundada sobre la necesidad de salvaguardar la sociedad democrática.

\section{- Sentencia del Tribunal Europeo de Derechos Humanos (Sección $3^{a}$ ), de 13 de abril de 2006 (TEDH 2006/30). Festividades religiosas. No se aprecia violación del art. 9}

Un ciudadano macedonio demanda a la Antigua República Yugoslava de Macedonia como consecuencia de las multas impuestas por ausentarse del trabajo en ciertas festividades religiosas. Los tribunales internos estimaron no creíble la afirmación del demandante acerca de su pertenencia a la religión islámica y declararon que cabía exigir una prueba en tal sentido, pues «las normas legales objetivas tienen preeminencia sobre la norma subjetiva al solicitar el ejercicio de derechos».

El Tribunal europeo concluye que no existe violación del artículo 9. En el contexto del empleo, con contratos que establecen obligaciones y derechos específicos para el empleador y para el empleado, es razonable que el primero pueda considerar la ausencia sin permiso como una cuestión disciplinaria. Cabe la analogía con el régimen de objeción de conciencia al servicio militar, en el que se admite que las autoridades pueden exigir pruebas contundentes de las genuinas objeciones religiosas.

No le asiste la razón al demandante cuando se considera la única persona practicante de la fe musulmana a la que se le exige probar la pertenen- 
cia a esa religión. No era poco razonable ni desproporcionado - pues reclamaba una exención a la que no tendría derecho a menos que perteneciera a la religión en cuestión de modo que no planteara duda - exigirle que demostrara algún nivel de sustanciación de su reclamación. No existe violación del artículo 14.

- Sentencia del Tribunal Europeo de Derechos Humanos (Sección $2^{a}$ ), de 7 de marzo de 2006 (TEDH 2006/19). Vida familiar. El debate gira en torno a los arts. 2, 8 y 14, que no se consideran violados

La demanda contra el Reino Unido es presentada por una ciudadana británica, como consecuencia de la denegación judicial del implante de los embriones congelados en el proceso de un tratamiento de fertilidad, al haber retirado el consentimiento el varón conviviente. Se discute el alcance del derecho a la vida, del derecho al respeto de la vida privada y familiar y de ciertas dimensiones de la prohibición de la discriminación.

Por lo que se refiere al artículo 2, establece el Tribunal que la legislación británica no reconoce al embrión la calidad de sujeto de derecho autónomo ni le autoriza a prevalerse del derecho a al vida, posición que debe admitirse a la vista, dice, «de la falta de un consenso europeo sobre la definición científica y jurídica del inicio de la vida».

El debate principal se desarrolla al hilo del derecho a la vida privada, reconocido en el artículo 8 . Se parte de una noción amplia de vida privada que engloba aspectos como el derecho a establecer relaciones con otros seres humanos y la decisión de tener un hijo. La controversia se contrae al punto de si recae sobre el Estado la obligación positiva de garantizar a las mujeres que se someten a tratamientos de FIV con el fin específico de dar a luz un hijo de su sangre la posibilidad de hacerse implantar un embrión concebido a partir de los gametos de su ex compañero cuando éste se retracta de su compromiso. El Tribunal secunda el criterio de la ley británica según el cual cada una de las personas afectadas por un tratamiento de FIV tiene libertad de retractarse hasta el momento de la implantación del embrión.

Las reclamaciones relativas a la discriminación resultante de las mujeres que se someten a FIV — que se encuentran a merced del donante de espermay las que tienen hijos en forma natural son rechazadas, pues los motivos que han llevado a concluir con la no violación del artículo 8 constituyen también una justificación objetiva y razonable a efectos del artículo 14 . 
- Sentencia del Tribunal Europeo de Derechos Humanos (Sección $2^{\underline{a}}$ ), de 17 de enero de 2006 (TEDH 2006/8). Traslado de restos mortales. No se aprecia violación del art. 8

La actora, de nacionalidad sueca, demanda al Reino de Suecia, al amparo del artículo 8 del Convenio - sobre el derecho a la vida privada y familiar- por la decisión del Tribunal administrativo que rechazó la autorización para trasladar la urna que contenía las cenizas de su marido de un panteón a otro. El Tribunal administrativo aplicó la Ley sueca basada en el respeto del carácter sagrado de la tumba, que obliga a una interpretación restrictiva de las disposiciones sobre el traslado de los restos mortales. El Gobierno no discute que la negativa al traslado supone una injerencia en la vida privada y familiar, conforme al número 1 del artículo 8 del Convenio, pero era «necesaria en una sociedad democrática» para la defensa del orden, la protección de la moral y/o los derechos de terceros. El litigio se plantea como un conflicto entre un interés particular y un valor social. El primero es el traslado de los restos mortales y el segundo el respeto al carácter sagrado de la tumba. El Tribunal considera que esta cuestión es tan importante y tan sensible que los Estados deben gozar de un amplio margen de apreciación y no encuentra violación del artículo 8 del Convenio.

Hay una Opinión disidente de tres jueces. En atención a las circunstancias del caso - la ausencia de conflicto familiar y la pretensión de trasladar los restos de un lugar sagrado a otro también sagrado- no se justifica la finalidad legítima de la limitación del derecho.

\section{- Sentencia del Tribunal Europeo de Derechos Humanos (Sección $2^{a}$ ), de 31 de enero de 2006 (TEDH 2006/12). Difamación. Violación del art. 10}

Un ciudadano austriaco demanda a la República de Francia a resultas de la condena impuesta por delito de difamación contra la comunidad cristiana. Como autor de un artículo publicado en un diario de difusión nacional, había vinculado la doctrina católica del cumplimiento de la Antigua en la Nueva Alianza con el antisemitismo en Europa, haciendo responsable a la Iglesia de la masacre de Auschwitz.

El Tribunal dictamina la violación del artículo 10 del Convenio. A su juicio, la injerencia en el ejercicio del demandante de su derecho a la libertad de expresión se encontraba prevista por la ley y tenía un fin legítimo, pero no 
era necesaria en una sociedad democrática. Considera que el autor ha querido elaborar una tesis sobre el alcance de un dogma y sus posibles vínculos con el origen del Holocausto. En el ámbito de las cuestiones de interés general en una sociedad democrática, las restricciones a la libertad de expresión requieren una interpretación estricta.

\section{TribunAl CONSTITUCIONAL}

Una única resolución del Tribunal Constitucional —la Sentencia 247/2006, de 24 de julio (RTC 2006/247) — se refiere a materia religiosa. La Sala de lo Social del Tribunal Supremo revocó la indemnización reconocida a profesor de religión en instancias inferiores por lesión del derecho de libertad sindical. Se otorga ahora amparo al demandante por lesión de la tutela judicial efectiva.

No son objeto de enjuiciamiento los artículos 14, 16.1 y 18.1 —invocados ahora por el actor- que no fueron considerados en el proceso judicial. La cuestión discutida se contrae a la efectividad de la tutela judicial de la libertad sindical, puesta en duda como consecuencia de la decisión de anular la condena indemnizatoria acordada en la instancia y confirmada en suplicación. Concluye el Tribunal que la denegación sin motivación razonable de cualquier indemnización a un trabajador que ha sufrido por parte de una Administración pública un comportamiento lesivo de de su derecho de libertad sindical de la índole, intensidad, reiteración y duración en el tiempo del analizado no puede considerarse suficiente para lograr una reparación real y efectiva del derecho fundamental vulnerado, que queda por ello desprotegido. Se aprecia también y en consecuencia la vulneración por la Sentencia recurrida del derecho de libertad sindical del demandante de amparo.

\section{TRIBUNAL SUPREMO}

\section{Profesores de religión}

La naturaleza de la relación jurídica y las reclamaciones de cantidad - salariales o de prestaciones sociales- acaparan la mayoría de las decisiones del Tribunal Supremo relativas a los profesores de religión. Son destacables determinadas resoluciones que reconocen el valor de la enseñanza religiosa escolar a los efectos de la cuantificación de méritos docentes en concursos públicos. 


\subsection{Carácter laboral de la relación}

- Sentencia del Tribunal Supremo (Sala de lo ContenciosoAdministrativo), de 16 de febrero de 2006 (RJ 2006/825)

Es bien sabido que la figura de funcionario interino exige la presencia inexcusable de un taxativo elemento normativo establecido en el artículo 5.2 de la Ley de Funcionarios Civiles del Estado (texto articulado de 7 de febrero de 1964): que dichos funcionarios interinos ocupen "plazas de plantilla en tanto se provean por funcionarios de carrera». Ese elemento normativo no concurre en los demandantes, desde el momento en que el específico cometido profesional desarrollado por ellos no constituye el contenido de ninguna plaza de la plantilla funcionarial de la Administración demandada. Lo que acaba de señalarse invalida el contraste en que se ha apoyado la Sala de instancia. El principio de igualdad actúa dentro de la legalidad, y la solución de la sentencia recurrida, por lo que se ha dicho, es contraria a la legalidad.

- Sentencia del Tribunal Supremo (Sala de lo Social), de 8 de junio de 2006 (RJ 2006/3452)

La falta de renovación de la propuesta por pare del Ordinario, en atención a los motivos discriminatorios que la motivaron, constituiría fundamento para la declaración de nulidad radical del despido de una profesora de religión. El recurso no cumple las condiciones requeridas desde el punto de vista procesal para que resulte admisible, defectos que hacen claudicar la pretensión. Ni el escrito de interposición del recurso expone una relación precisa y circunstanciada, ni se aprecia contradicción entre las sentencias que sirven de referencia a los efectos del proceso.

\subsection{Seguridad Social}

\section{- Sentencia del Tribunal Supremo (Sala de lo Contencioso-} Administrativo), de 13 de junio de 2006 (RJ 2006/4551)

La conflictividad que ha rodeado el régimen jurídico y económico de los profesores de religión, consecuencia de una larga desatención legislativa y del incumplimiento de compromisos retributivos por parte de la Administración, ha hecho que el proceso de transferencia de este personal a las Comunidades Autónomas haya generado ciertas disfunciones. Hay que estar en ca- 
da caso a los Acuerdos de transferencias realizadas por las Comisiones Mixtas, que podrían haber dejado a salvo de la asunción de cargas posibles deudas derivadas de sentencias judiciales y resoluciones administrativas de orden social. No sucede así en el caso, y el cumplimiento de las obligaciones derivadas del alta y cotización del profesorado de religión corresponde al Gobierno Autónomo.

- Auto del Tribunal Supremo (Sala de lo Social), de 15 de noviembre de 2006 (JUR 2007/37875)

Una vez más, se plantean dudas interpretativas acerca de la relación entre los Convenios de 1993 y 1999, sobre retribución del profesorado de religión. En este caso, a los efectos de fijar las bases de cotización determinante de la pensión de jubilación. Se discute si deberían haber sido derivadas de la aplicación del Convenio de 1993, en lugar de tomar como referencia el salario efectivamente percibido. El criterio jurisprudencial ya asentado para tomar en consideración las reclamaciones salariales devengadas al amparo del Convenio de 1993 es la constancia de que la Administración pagadora hubiese reconocido la retribución prevista en el mismo o el reconocimiento de ese derecho mediante Sentencia. No es el caso de la demandante, que no ostenta derecho alguno a que las bases de cotización debieran haber sido las derivadas del Convenio, por lo que deben ser las correspondientes al salario efectivamente percibido por la actora en dicho período.

\subsection{Experiencia docente}

- Sentencia del Tribunal Supremo (Sala de lo ContenciosoAdministrativo), de 17 de julio de 2006 (RJ 2006/5353)

La enseñanza de Religión impartida en condición de contratada laboral fija en un Instituto de Bachillerato debe ser valorada conforme a las normas específicas de la convocatoria (Cuerpo de Profesores de Enseñanza en la especialidad de Psicología y Pedagogía). La Sentencia confirma que del Real Decreto 2438/1994, de 16 de diciembre, por el que se regula la Enseñanza de la Religión se desprende que deben equipararse los servicios prestados por los profesores de Religión con los del resto del profesorado. Recuerda que todos han sido nombrados por la autoridad docente administrativa con carácter de interinos, sin más diferencia que el origen de la propuesta y su autor, ya que en un caso es el Ordinario del lugar y en el otro la bolsa de trabajo. 
- Sentencia del Tribunal Supremo (Sala de lo ContenciosoAdministrativo), de 25 de septiembre de 2006 (RJ 2006/6439)

La enseñanza religiosa escolar constituye «experiencia docente previa», alegable en el concurso a una plaza del Cuerpo de Profesores de Enseñanza Secundaria, especialidad Lengua castellana, en contra de quienes consideraban que era asignatura especial y de carácter no curricular. «Procede precisar que los nombramientos como profesores especiales de religión — cual el que justifica la experiencia docente previa de la actora - han venido siendo asimilados al nombramiento de interinos, si bien con alguna particularidad en la designación y cese de los mismos, que lo es por la autoridad académica competente, a propuesta del Ordinario del lugar, según determinan los Acuerdos entre la Santa Sede el Estado Español de 3 de enero de 1979 sobre Enseñanza y Asuntos Culturales (...). Consecuentemente, resulta procedente, en los términos que concluye la Administración demandada, la experiencia docente previa como profesor de religión en Instituto de Bachillerato».

\section{Impuesto sobre bienes inmuebles}

- Sentencia del Tribunal Supremo (Sala de lo ContenciosoAdministrativo), de 21 de septiembre de 2006 (RJ 2006/7462)

A tenor de la Ley de Fundaciones de 1994, las Universidades no se equiparan a las Iglesias en cuanto a la exención del IBI. «En la disposición adicional quinta dos no pueden entenderse comprendidas las Universidades, careciendo por ello de fuerza suficiente para reconocer los beneficios fiscales en tributos locales denegados por la disposición adicional 9 $9^{\underline{a}}$ de la Ley de Haciendas Locales».

\section{Libertad de enseñanza}

- Sentencia del Tribunal Supremo (Sala de lo ContenciosoAdministrativo), de 26 de junio de 2006 (RJ 2006/597)

El Tribunal Supremo afronta cuestiones de gran calado, relacionadas con los artículos 14, 16 y 27 de la Constitución. El recurso trae causa de la denuncia de un sindicato a propósito de los conciertos celebrados con determinados centros educativos.

La doctrina de mayor relevancia se refiere a la declaración de conformidad con la Constitución de la financiación pública, vía conciertos educativos, 
de la enseñanza separada de niños y niñas impartida en centros privados. Como resulta obligado a tenor del art. 10.2 de la Constitución, la Sala se remite a los textos internacionales sobre la materia, a la vista de los cuales no se puede asociar la enseñanza separada con la discriminación por razón de sexo. «No sólo porque así lo dice la Convención relativa a la lucha contra las discriminaciones en la esfera de la enseñanza, de 15 de diciembre de 1960 , art. 2. a) ${ }^{1}$, sino porque la Convención sobre la eliminación de todas las formas de discriminación contra la mujer, de 1979, en el artículo 10 c)², no hace más que indicar que el estímulo de la enseñanza mixta es una de las posibles vías para superar los estereotipos de los papeles masculino y femenino. No hay contradicción entre ellos y es distinta la fuerza normativa que despliegan, vista la estructura de uno y otro precepto. En el último caso, se afirma tajantemente que en las condiciones indicadas la enseñanza separada no discrimina por razón de sexo. En el primero, se dice que la enseñanza mixta es un medio, no el único, de promover la eliminación de aspectos de la desigualdad por razón de sexo».

En definitiva, el mero hecho de que se enseñe sólo a niños o a niñas no es en sí mismo discriminatorio por razón de sexo siempre que los padres o tutores puedan elegir, en un entorno gratuito de la enseñanza, entre los centros existentes en un determinado territorio. Indica, a este respecto, que el Real Decreto 366/1997, de 14 de marzo, por el que se regula el Régimen de Elección de Centro Educativo, no incluye el sexo entre las causas por las que no se puede discriminar en la admisión de alumnos a los centros públicos o concertados (artículo 3) e insiste en que la libertad de elección permite a los padres y tutores y, en su caso, a los alumnos, optar por uno u otro centro.

Añade el Tribunal que no habría motivo para negar el acceso al concierto a esos centros, aunque no satisfacieran necesidades de escolarización ni reu-

1. «En el caso de que el Estado las admita, las situaciones siguientes no serán constitutivas de discriminación el sentido del artículo 1 de la presente Convención (...) La creación o el mantenimiento de sistemas o establecimientos de enseñanza separados para los alumnos de sexo masculino y para los de sexo femenino, siempre que esos sistemas o establecimientos ofrezcan facilidades equivalentes de acceso a la enseñanza, dispongan de un personal docente igualmente calificado, así como de locales escolares y de un equipo de igual calidad y permitan seguir los mismos programas equivalentes».

2. «Los Estados Partes tomarán todas las medidas apropiadas para eliminar la discriminación contra la mujer, a fin de asegurarle la igualdad de derechos con el hombre en la esfera de la educación y en particular para asegurar, en condiciones de igualdad entre hombres y mujeres (...) c) La eliminación de todo concepto estereotipado de los papeles masculino y femenino en todos los niveles y en todas las formas de enseñanza, mediante el estímulo de la educación mixta y de otros tipos de educación que contribuyan a lograr este objetivo y, en particular, mediante la modificación de los libros y programas escolares y la adaptación de los métodos de enseñanza». 
nieran las demás condiciones que determinan preferencia a estos efectos, siempre que haya consignación presupuestaria y hayan sido atendidas la necesidades de sostenimiento de los centros preferentes. «No sólo no contradice ninguna norma, ni es incoherente con los elementos principales con los que el artículo 27 de la Constitución contempla el derecho a la educación, la libertad de enseñanza y el papel que el Estado debe desempeñar en relación con el primero y la segunda y con el derecho de los padres a que sus hijos reciban la formación religiosa y moral que esté de acuerdo con sus convicciones. Por lo demás, la previsión del apartado séptimo de este precepto constitucional ("Los poderes públicos ayudarán a los centros docentes que reúnan los requisitos que la Ley establezca") ofrece cobertura a una interpretación como la realizada por la Audiencia Nacional en función de lo que en aquel momento disponían las leyes».

- Sentencia del Tribunal Supremo (Sala de lo ContenciosoAdministrativo), de 11 de diciembre de 2006 (RJ 2007/577)

La ratificación en la Sentencia de instancia de la Orden que establecía el calendario escolar para los centros docentes no universitarios no puede decirse que vulnera los principios de autonomía organizativa, pedagógica y de gestión de los centros docentes ni que haya quebrantado la prohibición legal de que la Administración educativa adopte medidas que supongan su subrogación en las facultades del titular o del Consejo Escolar del centro. Como señala la sentencia de instancia, la determinación del calendario escolar por parte de la Administración educativa tiene cabida e las facultades que se reconocen a ésta en orden a la homologación de sistema educativo.

\section{Inscripción de bienes inmuebles}

- Sentencia del Tribunal Supremo, (Sala de lo Civil), de 16 de noviembre de 2006 (RJ 2006/8055)

El Ayuntamiento ejercitó acción reivindicatoria sobre una Ermita-Santuario inscrita a nombre del Arzobispado, invocando mejor título de dominio, a fin de que se declarara su derecho de propiedad sobre la ermita, se condenara al cese de actos posesorios y a la cancelación de la inscripción registral.

No se estima la inconstitucionalidad pretendida del artículo 206 de la Ley Hipotecaria, que atribuye a las corporaciones o servicios de la Iglesia católica la posibilidad de inscribir bienes inmuebles en el Registro de la Propiedad, cuando carezcan de título escrito de dominio, mediante la certificación que 
contempla el mencionado artículo. Funda su posición la Sala en que «el Ayuntamiento demandante, recurrente en casación, no puede alegar discriminación ni atentado al principio de igualdad, siendo así que también el mismo goza de idéntica atribución, ni puede como tal mantener el principio de igualdad respecto a otras Iglesias, ni, por último, puede obviarse que el párrafo segundo de aquella norma ha sido introducido por el artículo 144 de la Ley 13/1996, de 30 de diciembre, de medidas fiscales, administrativas y de orden social, sin que se haya cuestionado nunca la posible inconstitucionalidad de todo el precepto».

La segunda cuestión es la validez de la certificación que dio lugar a la inscripción del dominio de la ermita a favor del Arzobispado ${ }^{3}$. En el caso presente, «la certificación fue librada por el Canciller-secretario de la diócesis, que carece de la facultad de administración y tiene en exclusiva la de expedir certificaciones, conforme a su legislación propia (Código de Derecho Canónico, cánones 482,1 y 484.3) que es la aplicable como regulación interna de la Iglesia católica, conforme al artículo 1.4, que le reconoce la personalidad jurídica civil y plena capacidad de obrar, del Acuerdo sobre asuntos jurídicos suscrito por la Iglesia y el Estado de fecha 3 de enero de 1979. Tratado internacional integrante del ordenamiento jurídico español conforme al artículo 96 de la Constitución Española».

Sobre el dominio de La Ermita, al Ato Tribunal ratifica el juicio de la Sala territorial en el sentido de que el Arzobispado mantiene su título de dominio que justifica sus posesión y se apoya en la inscripción en el Registro de la Propiedad.

\section{AUdienCIA NACIONAL}

\section{Profesores de religión}

- Auto de la Audiencia Nacional (Sala de lo ContenciosoAdministrativo), de 11 de enero de 2006 (JUR 2006/120951)

La Ley 29/1998, Reguladora de la jurisdicción contencioso-administrativa, introdujo la figura de la extensión de los efectos de determinadas sentencias a terceros que no hubieran sido parte en el proceso. Uno de los requisitos

3. El artículo 206 de la Ley Hipotecaria establece que la certificación la libre el funcionario a cuyo cargo esté la administración de los bienes que se inscriben y el artículo 304 del Reglamento Hipotecario aclara que, tratándose de bienes de la Iglesia, las certificaciones serán expedidas por los diocesanos respectivos. 
para que pueda prosperar es que la doctrina determinante del fallo cuya extensión se postule no resulte contraria a la jurisprudencia del Tribunal Supremo. Numerosas resoluciones de la Audiencia Nacional desestiman recursos de apelación presentados por profesores de religión contra la negativa al reconocimiento de los mencionados incidentes de extensión de efectos para obtener el cobro de diferencias retributivas. La desestimación viene impuesta porque la doctrina determinante del fallo cuya extensión se postula es contraria a la jurisprudencia del Tribunal Supremo, que determina la naturaleza laboral y por tanto la incompetencia, por falta de jurisdicción, de la contencioso-administrativa para resolver la cuestión retributiva de los profesores de religión en centros públicos. Refuerzan la tesis recientes sentencias del Tribunal Supremo (19 de enero de 2005 [RJ 2005/1737], 16 de junio de 2005 [RJ 2005/9680]) que reinciden en la conclusión de que la relación jurídica de los profesores de religión no entraña la condición de funcionario interino y en la competencia de la jurisdicción social para decidir las consecuencias jurídicas de tal relación.

\section{Exención del Impuesto sobre el Valor Añadido}

- Sentencia de la Audiencia Nacional (Sala de lo ContenciosoAdministrativo), de 17 de julio de 2006 (JUR 2006/245668)

No existe razón para cuestionar la concesión de la exención del IVA a un Instituto religioso por las obras de construcción de un centro educativo, pues la Orden de 29 de febrero de 1988 del Ministerio de Economía y Hacienda subordina la concesión de dicha exención tributaria al cumplimiento de unos requisitos subjetivos y objetivos que están presentes en este caso. Los requisitos subjetivos consisten en que los adquirentes de los bienes sean la Santa Sede, la Conferencia Episcopal, las diócesis, las parroquias, las Órdenes y Congregaciones religiosas y los Institutos de vida consagrada, concurriendo dicho requisito en las dos Comunidades religiosas que encargaron la realización de las obras, lo que no se cuestiona por la recurrente. Los requisitos objetivos exigen que los bienes adquiridos se destinen al culto, pero también cabe que se destinen a la sustentación del clero, al sagrado apostolado o al ejercicio de la caridad, y las obras realizadas tenían precisamente por fines la sustentación del clero, el ejercicio del apostolado y de la caridad que realizan las Comunidades religiosas con niños/as y jóvenes de ambientes populares.

La empresa recurrente era perfecta conocedora de que el pago de las obras que contrataron las Comunidades religiosas estaba exento del IVA, como lo demuestra las certificaciones de obras emitidas, en las que la empresa recurrente no repercutió el Impuesto. La recurrente era libre de aceptar o no la rea- 
lización de las obras, pero en caso de aceptarlas, debía aceptar igualmente que el precio pactado estaba exento del IVA, con las consecuencias que ello tendría al liquidar el Impuesto.

El segundo de los argumentos de la demanda, contradictorio con el primero, sostiene que la exención del pago del IVA reconocida a las dos Comunidades religiosas es un supuesto de exención plena, que habilita el derecho a deducir, de acuerdo con el artículo 22.8 de la Ley 37/1992, de 28 de diciembre, reguladora del IVA (LIVA), que se refiere a las entregas de bienes y prestaciones de servicios realizadas en el marco de las relaciones diplomáticas y consulares, en los casos y con los requisitos que se determinen reglamentariamente.

Resulta, de acuerdo con el artículo 10, apartados 3 y 5, del RD 1624/1992, de 29 de diciembre, por el que se aprueba el Reglamento del IVA, que las exenciones en operaciones asimiladas a las exportaciones a que se refiere el artículo 22.8 LIVA, realizadas en el marco de las relaciones diplomáticas y consulares, son las entregas de bienes y prestaciones de servicios a Estados extranjeros para ser utilizadas por sus representaciones diplomáticas y oficinas consulares, mientras que las diócesis, parroquias, Órdenes y Congregaciones religiosas e Institutos de vida consagrada, en cuyo beneficio cabe conceder la exención del IVA, desarrollada por la Orden del 29 de febrero de 1988, no son sujetos de Derecho Público Internacional, ni gozan de estatuto diplomático como representación del Estado del Vaticano, de forma que les es inaplicable la exención del artículo 22.8 LIVA.

\section{Seguridad Social}

- Sentencia de la Audiencia Nacional (Sala de lo ContenciosoAdministrativo), de 29 de mayo de 2006 (JUR 2006/165240)

Muestra la parte actora su disconformidad con la obligación que el artículo 5.1 del RD 432/2000 le impone de satisfacer el capital coste en la pensión de jubilación reconocida, así como con el hecho de que no se efectúe el cómputo de hasta cinco años de servicios previsto en la Ley 33/1987, alegando en síntesis que «la disposición adicional décima de la Ley 13/1996, de 31 de diciembre, no crea prestación económica ni carga alguna, ni impone obligación de pagar cuotas, cánones, tasas, u otros gravámenes, por el cómputo del tiempo que estuvo ejerciendo como sacerdote, a efectos de completar 35 años, para reconocerle la pensión de jubilación por el cien por cien del haber regulador. Que la "parte de pensión a cargo del interesado" creada por el Real Decreto 432/2000 para Clases Pasivas y que tiene que abonar el pensionista, es una pres- 
tación patrimonial de carácter público y se ha creado ex novo por dicho Real Decreto, así como que existe reserva de Ley para la creación de estas prestaciones, cuotas y obligaciones patrimoniales, que constituyen ingresos de derecho público. Que la disposición adicional decimonovena de la Ley 33/1987, de 23 de diciembre, creó el derecho a un abono especial para funcionarios de determinados Cuerpos docentes que reunieran determinados requisitos, de hasta cinco años, hasta completar 30 años de servicios efectivos al Estado en dicha actividad docente, derecho que reglamentó la disposición adicional segunda del Real Decreto 202/1988, de 11 de marzo, reuniendo el recurrente los requisitos exigidos y teniendo por tanto derecho a dicho abono especial; pero el art. 2.2 del Real Decreto 432/2000 elimina ese derecho creado por la citada Ley, vulnerando la misma».

La pretensión es rechazada, con apoyo en doctrina bien conocida de la propia Sala, fundada sobre dictamen del Consejo de Estado en relación con el Proyecto de Real Decreto por el que se regula el cómputo en el Régimen de Clases Pasivas del Estado de los períodos reconocidos como cotizados a la Seguridad Social a favor de sacerdotes y religiosos o religiosas de la Iglesia católica.

\section{TRIBUNALES SUPERIORES DE JUSTICIA}

La enorme masa de resoluciones judiciales fruto de la actividad de los Tribunales Superiores constituye un elemento muy estimable para el conocimiento del derecho real en materia religiosa, por más que las sentencias dictadas no formen parte de la jurisprudencia, a tenor de lo establecido en el art. 1.6 del Código Civil. Desde el punto de vista cuantitativo es, como siempre, la parte más relevante de esta Crónica.

\section{Libertad religiosa}

- Sentencia del Tribunal Superior de Justicia del País Vasco (Sala de lo Social), de 21 de febrero de 2006 (JUR 2006/175795)

La negativa del Servicio público de Salud a realizar una intervención quirúrgica tras oponerse la paciente a una eventual transfusión de sangre obligó a la recurrente a acudir a un centro privado y pretende el reintegro de los gastos médicos.

La Sala resuelve con arreglo a doctrina del Tribunal Supremo, en Sentencia de 14 de abril de 1993, según la cual «el Estado debe respetar las creen- 
cias religiosas; pero no tiene el deber de financiar aquellos aspectos de las mismas que no sean acreedores de protección o fomento desde el punto de vista general», por lo que «en definitiva ha de concluirse que las consecuencias de todo orden (también las económicas) que derivan del precepto religioso que nos ocupa han de ser asumidas por quien al mismo quiera atenerse».

La propia Sala había resuelto un supuesto esencialmente similar, en Sentencia de 20 de mayo de 1994. Se admite la razonabilidad, desde un punto de vista humano y religioso, de exigir no ser sujeto a transfusiones de sangre pero es irrazonable, si peligra la vida, desde el punto de vista sanitario, pues su no realización supondría para el equipo sanitario una «eutanasia», penada en el art. 409 del Código Penal, sin que a ello obstase la voluntad concurrente del sujeto intervenido quirúrgicamente.

- Sentencia del Tribunal Superior de Justicia de Valencia (Sala de lo Contencioso-Administrativo), de 21 de febrero de 2006 (JUR 2006/222007)

Mediante Auto del Juzgado de lo Contencioso-Administrativo se dispuso la suspensión de la Resolución de la Corporación Municipal que establecía, entre otras cosas, la obligación del recurrente en la instancia — policía localde acompañar determinada procesión de carácter tradicional.

La Corporación apelante niega que la medida cautelar produzca el resultado - como exige el art. 130.1 de la Ley Jurisdiccional para que resulte admisible — de la pérdida de la finalidad legítima del recurso y, en cambio, sí que se produciría perturbación del interés general con la suspensión acordada, como establece le número 2 del mismo artículo. La discusión de la doctrina del periculum in mora se decanta finalmente de parte de la interpretación del Juzgador de instancia en la medida que «invocada por el actor la vulneración de su libertad religiosa es claro que de no suspenderse el acto impugnado dicha vulneración se produciría, en la medida que el dicho acto regula, entre otros aspectos, la obligación del Intendente de la Policía Local — cargo que aquél ostenta- de acompañar determinada procesión de carácter tradicional en la población. Y sin que se aprecien superiores razones de interés general (según la Corporación Municipal se socava su autoridad), pues no en vano la Jefatura de la Policía Local se corresponde con un cargo, no con un "individuo" particularizado, de manera que pueden actuarse los adecuados mecanismos de sustitución al objeto de articular la representación de la Policía Local en el evento indicado, al menos de forma cautelar y en tanto se resuelva el recurso». 


\section{Régimen tributario}

\subsection{Impuesto de Sociedades}

- Sentencia del Tribunal Superior de Justicia de Madrid (Sala de lo Contencioso-Administrativo), de 9 de marzo de 2006 (JT 2006/738)

Una asociación religiosa católica recurre la Resolución del TEAR de Madrid sobre liquidación provisional del Impuesto de sociedades buscando amparo en el art. V del Acuerdo entre la Santa Sede y el Estado español sobre asuntos económicos y en la Ley 30/1994, de Fundaciones y de Incentivos Fiscales a la participación privada en actividades de interés general, para tributar al tipo del 10\% en lugar del correspondiente al 25\%.

Asunto semejante fue resuelto por la misma Sala, mediante Sentencia de 18 de mayo de 2005, que introdujo un criterio interpretativo del artículo $\mathrm{V}$ del Acuerdo celebrado entre la Santa Sede y el Estado español sobre asuntos económicos ${ }^{4}$, y que puede expresarse en los siguientes términos: el Tribunal entiende que el referido artículo $\mathrm{V}$ del Acuerdo sobre asuntos económicos no establece un concreto beneficio fiscal, en cuyo caso no podría ser modificado por la legislación interna española, sino que constituye una norma de remisión al Ordenamiento jurídico-tributario del Estado Español, por lo que no puede considerarse que la legislación interna española sólo sea aplicable en cuanto establece la bonificación del 10\% prescindiendo de los requisitos que establece para su concesión, sino que la remisión al Ordenamiento jurídicotributario del Estado Español ha de efectuarse en tu totalidad respecto del beneficio controvertido, debiendo concurrir los requisitos que establece dicho Ordenamiento (en la referida Ley 30/1994, de 24 de noviembre, de Fundaciones y de Incentivos Fiscales a la participación privada en actividades de interés general).

La recurrente no acreditó en el ejercicio objeto de controversia el cumplimiento de dichos requisitos. Concretamente, la acreditación en tiempo oportuno de su naturaleza de entidad sin fines lucrativos.

4. «Las asociaciones y entidades religiosas no comprendidas entre las enumeradas en el artículo IV de este Acuerdo y que se dediquen a actividades religiosas, benéfico-docentes, médicas u hospitalarias o de asistencia social tendrán derecho a los beneficios fiscales que el ordenamiento jurídico-tributario del Estado español prevé para las entidades sin fin de lucro y, en todo caso, los que se conceden a las entidades benéficas privadas». 


\subsection{Impuestos reales}

- Sentencia del Tribunal Superior de Justicia de Extremadura (Sala de lo Contencioso-Administrativo), de 17 de enero de 2006 (JUR 2006/108974)

(De la misma Sala, en idéntico sentido, Sentencias de 25 [JT 2006/1187] y 26 de mayo de 2006 [JUR 2006/215549])

La Asamblea de Extremadura, mediante Ley 9/1998, de 26 de junio, estableció un impuesto sobre Suelo sin edificar y edificios ruinosos. El art. 6 no establece expresamente exención en favor de la Iglesia católica y el impuesto se gira a los inmuebles propiedad de la diócesis. La cita del art. IV b) del Acuerdo sobre asuntos económicos — «la Santa Sede, la Conferencia Episcopal, las diócesis, las parroquias y otras circunscripciones territoriales, las Órdenes y Congregaciones religiosas y los Institutos de vida consagrada y sus provincias [gozarán de] b) Exención total y permanente de los impuestos reales o de producto, sobre la renta y sobre el patrimonio»— es suficiente para comprobar que, siendo el impuesto discutido de naturaleza real, cae dentro de la norma citada. No cabe oponer a tales argumentos el hecho de que el Acuerdo se firmase en un momento en que el Ordenamiento Tributario no recogía tributos como el que nos ocupa, porque la referencia absoluta a todo Impuesto de naturaleza real afectaría pro futuro a todo tributo de esa naturaleza, como lo es el de autos. Abunda en la tesis con la referencia a la Orden de 29 julio 1983, que expresamente contemplaba la exención del viejo Impuesto sobre Solares de naturaleza Municipal.

\subsection{Impuesto sobre el Valor Añadido}

Se cuestiona, a veces, la condición de la persona beneficiaria de la exención o la naturaleza de los trabajos que hacen aplicable la exención del IVA. La Sentencia del Tribunal Superior de Justicia de Madrid (Sala de lo Contencioso-Administrativo), de 18 de mayo de 2006 (JUR 2006/194360) entiende que, con arreglo al art. IV del Acuerdo y al art. 2 de la Orden del Ministerio de Economía de 29 de febrero de 1988, no hay duda de que la parroquia es sujeto beneficiario de la exención del impuesto sobre el IVA. Por otra parte, las obras cuestionadas «tenían por objeto restaurar el techo, cercos de vidrieras, tabiques y escalera del templo parroquial, así como la adaptación de las instalaciones ac- 
cesorias a tales elementos, por lo que su finalidad era rehabilitar el edificio mediante su consolidación, excediendo del $20 \%$ de la base imponible el coste de los materiales aportados».

La misma Sala, en Sentencia de 31 de marzo de 2006 (JUR 2006/186438), determina que procede la exención del impuesto, en contra de lo apreciado por la Administración, pues «la obra a realizar sí debe ser calificada de rehabilitación del inmueble por su envergadura. Se trata de una obra que afecta a la totalidad del templo, reacondicionado tanto en el interior como el exterior del edificio, así como las dependencias parroquiales, con el acometimiento de servicios que hasta la fecha no tenían».

- Sentencia del Tribunal Superior de Justicia de Extremadura (Sala de lo Contencioso-Administrativo), de 30 de marzo de 2006 (JUR 2006/140381)

La naturaleza jurídico-canónica de Caritas diocesana y su incardinación, a los efectos fiscales, en el art. IV o V del Acuerdo sobre asuntos económicos no resultan pacíficas. La interesante argumentación del Órgano juzgador se expresa en estos términos: «es una entidad con personalidad jurídica propia, tanto eclesiástica como civil, actúa con libre iniciativa y responsabilidad y goza de autonomía propia y plena en la administración de los bienes y de los recursos, dentro de los márgenes señalados en la legislación canónica (artículo 2 de sus Estatutos). Obviamente, como no puede ser menos en una entidad creada por la Iglesia, comparte con ésta parte de sus fines (de no ser así no podría estar incluida siquiera en el artículo V del Acuerdo). Tampoco es extraño que sea dirigida por órganos de la Iglesia Católica (en concreto, el Obispo), pues precisamente se trata de un ente creado por ésta para el cumplimiento de fines propios y respecto de la que es lógico ostente el debido control. Sin embargo, lo que no puede pasarse por alto es que la Iglesia ha optado libremente por no desempeñar aquellas actividades directamente a través de los órganos propios de la diócesis, sino mediante un ente con personalidad jurídica propia que, por ello mismo, cae de lleno en el ámbito previsto en el artículo $\mathrm{V}$ del Acuerdo. No puede pretenderse disponer de un ente diferenciado de la propia Iglesia (aunque lógicamente vinculado a ella) para el tráfico jurídico y económico, beneficiándose de los efectos de este régimen, pero no admitir las consecuencias negativas que puedan derivarse de tal utilización». Se deniega, en consecuencia, la exención del impuesto. 


\subsection{Impuesto sobre bienes inmuebles}

- Sentencia del Tribunal Superior de Justicia de Castilla y León (Sala de lo Contencioso-Administrativo), de 21 de marzo de 2006 (JUR 2006/140835)

Se aplica la liquidación del IBI sobre un hospital de titularidad religiosa, aplicando la exención tan sólo respecto de la zona del edificio destinado a uso religioso (Capilla, Convento o Casa de la Orden Hospitalaria). No considera el órgano juzgador que la actividad hospitalaria desarrollada pueda estimarse carente de ánimo de lucro. Funda su posición sobre la que considera doctrina legal vigente desde la Sentencia del Tribunal Supremo de 16 de junio de 2000, según la cual «para entender procedente la exención pretendida, es necesario que junto al elemento subjetivo (es decir, que se trate de la Iglesia Católica o de entidades religiosas comprendidas en los arts. IV y V del Acuerdo suscrito entre el Estado Español y la Santa Sede, sobre asuntos Económicos, el 3 de Enero de 1979), concurra el elemento u objetivo finalístico de la afectación del bien, debiendo acreditarse por ello que el bien transmitido se halla afecto a actividades o finalidades religiosas, entre ellas las de culto, sustentación del Clero, Sagrado apostolado y ejercicio de la caridad, benéfico docentes, medicas y hospitalarias o de asistencia social (véase ahora el art. 15 de la Ley 49/2002, de 23 de diciembre)».

(De la misma Sala, Sentencia de 2 de mayo de 2006 [JT 2006/799]).

\subsection{Impuesto sobre el incremento del valor de los terrenos}

En relación con las variadas alegaciones contra la liquidación del Impuesto sobre el incremento del valor de los terrenos de naturaleza urbana presentadas por entidades religiosas los órganos juzgadores reiteran la doctrina legal, ya citada en estas páginas, según la cual «para entender procedente la exención pretendida, es necesario que junto al elemento subjetivo (es decir, que se trate de la Iglesia Católica o de entidades religiosas comprendidas en los arts. IV y V del Acuerdo suscrito entre el Estado Español y la Santa Sede, sobre asuntos Económicos, el 3 de Enero de 1979, extremo no discutido el presente recurso contencioso-administrativo), concurra el elemento u objetivo finalístico de la afectación del bien, debiendo acreditarse por ello que el bien transmitido se halla afecto a actividades o finalidades religiosas, entre ellas las de culto, sustentación del Clero, Sagrado apostolado y ejercicio de la caridad, benéfico docentes, médicas y hospitalarias o de asistencia social (v. ahora el art. 15 de la Ley 49/2002, de 23 de diciembre)». 
Así, por ejemplo, en Sentencia del Tribunal Superior de Justicia de La Rioja (Sala de lo Contencioso-Administrativo), de 18 de julio de 2006 (JUR 2006/245637), a propósito de la transmisión de fincas por Caritas diocesana: «El artículo IV y V del Acuerdo en relación con los artículos 106 y 107 b) de la Ley de Haciendas Locales y la Ley 30/1994, de 24 de noviembre, de Fundaciones, en su disposición adicional $5^{\underline{a}}$, apartado 1 , no eximen del impuesto ante la mera titularidad de un inmueble por una de las entidades incluidas en el referido Acuerdo con la Santa Sede, sino que es preciso que tal bien esté destinado al ejercicio de la actividad propia de la entidad, sin que el requisito concurra en el presente caso».

También, en Sentencia del Tribunal Superior de Justicia de Castilla y León (Sala de lo Contencioso-Administrativo), de 13 de enero de 2006 (JUR 2006/52488), sobre liquidación del Impuesto por la transmisión de la titularidad de un hospital cuya inactividad a lo largo de setenta años no permitió acreditar su afectación directa a actividades o finalidades religiosas.

Asimismo, Sentencia del Tribunal Superior de Justicia de Navarra (Sala de lo Contencioso-Administrativo), de 29 de marzo de 2006 (JUR 2006/153040). La adquisición del inmueble por parte de una compañía mercantil demuestra el afán de lucro que animaba la operación. «Para aplicar o no la exención es determinante considerar si la finca objeto de transmisión se hallaba en el pasado afecta a alguna de las finalidades descritas y si en el futuro va a seguir tal destino o similar dentro de los enunciados, en cuyo caso se le aplicará la exención, o por el contrario si tal afectación la tenía en el pasado, pero ha dejado de tenerla y en el futuro próximo va a tener un mero destino mercantil, en cuyo caso no procederá la exención».

\section{Profesores de religión}

\subsection{Exclusión del ámbito del Convenio colectivo}

- Sentencia del Tribunal Superior de Justicia de Madrid (Sala de lo Social), de 16 de enero de 2006 (JUR 2006/129228)

Admite la Sala demanda por despido de una profesora de religión que vio unilateralmente rescindido su contrato por haber alcanzado la edad de jubilación. La especialidad de la relación de los profesores de religión justifica la exclusión del Convenio Colectivo de aplicación en el sector y con ello de la obligatoriedad de la jubilación a la edad predeterminada. No se puede olvidar que el Convenio celebrado entre el Ministerio de Educación y la Conferencia 
Episcopal Española, aprobado mediante Orden de 9 de abril de 1999, establece la equiparación entre profesores de religión e interinos a efectos retributivos, pero no se extiende a otros aspectos de su estatuto. La diferencia de trato está justificada. No se declara la nulidad del despido sino su improcedencia, porque no es la edad la razón del despido, sino la incorrecta aplicación de una norma colectiva que lo posibilita.

\subsection{Experiencia docente}

- Sentencia del Tribunal Superior de Justicia de Extremadura (Sala de lo Contencioso-Administrativo), de 7 de febrero de 2006 (JUR 2006/105497)

La enseñanza de religión es una válida experiencia docente para el acceso a plazas del Cuerpo de Maestros. No es óbice que la Religión no figura como especialidad propia del Cuerpo mencionado. Sin embargo, la enseñanza religiosa «forma parte del elenco de áreas en todos los niveles comprendidos en la LOGSE, de oferta obligatoria y sujeta en su impartición a las mismas prescripciones que las demás asignaturas fundamentales, sin otro elemento diferenciador que ser necesario un placet o juicio favorable del Ordinario diocesano en la designación del profesor, con lo que es innegable la experiencia docente alcanzada mediante su impartición que, genéricamente, es el mérito que se trata de valorar, pudiendo ser entendido el término especialidad utilizado por los subapartados objeto de controversia, a esos solos efectos, como área educativa. La solución contraria vulneraría la equiparación, establecida en los Acuerdos entre la Santa Sede y el Estado Español antes aludidos, de dicha asignatura con las restantes, equiparación que, por lo que se refiere a los aspectos estrictamente educativos, como lo es el que nos ocupa, ha sido reconocida por el Tribunal Supremo en su Sentencia de 14 de abril de 1998, dictada en el recurso contra el Real Decreto 2438/1994, de 16 de diciembre (Fundamento de derecho quinto)».

\subsection{Carácter laboral de la relación}

La jurisdicción Contencioso-Administrativa es competente para determinar si la relación de dependencia de la Administración es laboral o administrativa y, aunque no se hubiera formalizado en esos términos anteriormente, hay que concluir que la de los profesores de religión es de carácter laboral. Por tal motivo, no corresponde a esa jurisdicción pronunciarse sobre concretas reclamaciones por diferencias retributivas y se devuelven las actuaciones a la Sala Social. Así se expresa la Sentencia del Tribunal Superior de Justicia de Madrid 
(Sala de lo Contencioso-Administrativo), de 20 de enero de 2006 (JUR 2006/131083) y, en el mismo sentido, la del Tribunal Superior de Justicia de Asturias (Sala de lo Contencioso-Administrativo), de 13 de septiembre de 2006 (JUR 2006/258145).

- Sentencia del Tribunal Superior de Justicia de Canarias (Sala de lo Social), de 25 de octubre de 2006 (AS 2006/3216)

Debe abonarse el complemento específico de personal directivo a una profesora de religión que recibió el correspondiente nombramiento por parte de la Administración. Un Decreto autonómico admite que, en ausencia de funcionario, cualquier profesor puede ser nombrado para ocupar cargos directivos. «La demandante es personal laboral sujeta al Estatuto de los Trabajadores, que en su artículo 39 establece el derecho de los trabajadores que realizan trabajos de superior categoría a percibir la retribución correspondiente a la misma».

- Sentencia del Tribunal Superior de Justicia de Asturias (Sala de lo Contencioso-Administrativo), de 20 de marzo de 2006 (JUR 2006/148744)

Las certificaciones de servicios computables no pueden ser extendidas por responsables de entidades u organizaciones de ámbito ajeno a la Administración Pública. Sin embargo, el Tribunal admite el certificado emitido por el Arzobispado para reconocer los servicios prestados por el recurrente durante el tiempo que ejerció como profesor de religión. Actuar de modo distinto sería tanto como exigir que se aporte una prueba diabólica, pues quien puede expedir el certificado es quien se lo niega.

\subsection{Horarios}

- Sentencia del Tribunal Superior de Justicia de Canarias (Sala de lo Social), de 17 de abril de 2006 (JUR 2006/190551)

La norma correspondiente al régimen de Institutos de Enseñanza Secundaria contempla la posibilidad de dispensar de hasta tres horas lectivas a profesores mayores de 60 años, en atención a la plantilla del centro. Se niega, sin embargo, el derecho invocado a la reducción del horario lectivo del profesor de religión, por no existir otros profesionales que puedan suplir dicho horario y haber sido contratado con asignación determinada del número de horas. 
- Sentencia del Tribunal Superior de Justicia de Madrid (Sala de lo Social), de 24 de abril de 2006 (AS 2006/1733)

Se pide que las horas dedicadas a la Jefatura de Departamento se computen a efectos de tiempo de actividad lectiva, de manera que permitan reconocer una jornada completa y acceder a la categoría contractual deseada. La dedicación añadida, sin embargo, se ha realizado sin autorización alguna y no puede ser compensada en concepto de salario. El contenido del contrato de trabajo viene definido por el conjunto de cometidos que el trabajador se compromete a realizar en cumplimiento de lo expresamente pactado, sujetándose a las órdenes del empresario. Es la ejecución de lo pactado la circunstancia que genera el derecho a percibir el salario, no la realización de cometidos que, como en el caso presente, no han sido autorizados ni consta la necesidad o las circunstancias que han podido determinarlos.

Nada tiene que ver el hecho de que por Sentencia del mismo Tribunal hubiera declarado anteriormente la ilegalidad de la disposición que requería la autorización eclesiástica para ejercer la jefatura del Departamento de religión, pues no se trata de esa sino de la de la autoridad administrativa.

- Sentencia del Tribunal Superior de Justicia de Murcia (Sala de lo Social), de 26 de septiembre de 2006 (JUR 2006/257535)

Reclamación de cantidad para obtener el abono de los desplazamientos, con arreglo a las normas relativas a profesores itinerantes. En efecto, «se ha de aplicar la reducción de horas sobre la totalidad de la jornada de trabajo semanal, puesto que el tiempo invertido en los desplazamientos tiene carácter de trabajo efectivamente realizado y no solamente sobre las horas de obligada permanencia en el centro, pues las horas de preparación también tienen la consideración de horas de trabajo, por lo que si no se compensa en reducción de horas, se ha de compensar económicamente».

\subsection{Indemnización por término de contrato}

De acuerdo con lo establecido por Sentencia del Tribunal Supremo de 16 de junio de 2004 (RJ 2004/5583), los profesores de religión en centros públicos dependientes de la Administración Autonómica tienen derecho a la indemnización por finalización contrato prevista en el artículo 49.1.c) del Estatuto de los Trabajadores. En tal sentido, la Sentencia del Tribunal Superior de Justicia de Castilla La Mancha (Sala de lo Social), de 21 de septiembre de 
2006 (JUR 2006/257710) reconoce tal derecho, «sin que ello signifique un trato desigual respecto de los profesores interinos, alegado por la recurrente, por cuanto es sobradamente conocida la doctrina constitucional sobre el significado del principio de igualdad - tratamiento igual para situaciones y condiciones iguales que permite diferencias de regulación o de trato por causas objetivas y justificadas-, y su alcance respecto de situaciones concretas, como la regulación normativa diferenciada de la relación de prestación de servicios a la Administración pública a través de una relación laboral, de una relación funcionarial o de una relación estatutaria». No puede ser admitida la petición subsidiaria formulada en el suplico del escrito de recurso sobre la admisión del derecho a la indemnización referida exclusivamente a los trabajadores cuyos contratos no sean renovados para el siguiente curso escolar, porque como expresa el Tribunal Supremo en la tan citada Sentencia de 16 de junio de 2004 (RJ 2004/5583), la relación laboral se extingue con independencia de que el trabajador sea nombrado de nuevo para el siguiente curso escolar.

En el mismo sentido, Sentencia del Tribunal Superior de Justicia de Extremadura (Sala de lo Social), de 19 de septiembre de 2006 (JUR 2006/257897), con cita de la doctrina del Tribunal Supremo en Sentencia de 7 de noviembre de 2005. Y también, Sentencia del Tribunal Superior de Justicia de Castilla y León (Sala de lo Social), de 14 de julio de 2006 (AS 2006/2320). Según esta última, «la equiparación de los profesores de religión con el personal interino se limita al aspecto meramente retributivo y no a la naturaleza de la relación laboral, pues los profesores de Religión no cubren una vacante existente hasta que la ocupe su titular, que es lo propio de la interinidad. Así las cosas, es claro que a la relación laboral de los profesores de Religión, con independencia del peculiar sistema de contratación, le resulta de aplicación la normativa contenida en el Estatuto de los Trabajadores en cuanto a la verdadera naturaleza de la relación laboral, que no es otra que la propia que los contratos de relación laboral para servicio determinado, es decir, para el curso escolar para el que son contratados. Pues bien, el artículo 49.1 c) del Estatuto de los Trabajadores prevé para este tipo de contratos y a su conclusión una indemnización a favor del trabajador de 8 días de salario por cada año de servicio, derecho que legalmente reconocido es irrenunciable lo que acarrea que la cláusula $8^{\mathrm{a}}$ del contrato suscrito por la actora se tenga por nula por contraria a la Ley. A lo dicho no obsta que pueda existir continuidad entre un contrato y otro, porque tal circunstancia, no garantizada para el trabajador precisamente por el peculiar sistema de nombramiento o contratación, no desvirtúa la naturaleza temporal para el servicio determinado del contrato suscrito». 


\subsection{Complemento salarial de antigüedad}

- Sentencia del Tribunal Superior de Justicia de Castilla y León (Sala de lo Social), de 13 de marzo de 2006 (JUR 2006/110261)

La cuestión del complemento salarial de antigüedad de los profesores de religión ya ha sido abordada y resuelta por el Tribunal Supremo sobre la base de la especialidad o, cuanto menos, singularidad de la relación, que cuenta con fuentes reguladoras propias en un Tratado internacional (entre las múltiples sentencias, cabe citar 5 de junio de 2000 [RJ 2000/4650], 7 de julio de 2000 [RJ 2000/6295], 17 de julio de 2000 [RJ 2000/7184], 11 de octubre de 2000 [RJ 2000/9426], 4 de diciembre de 2000 [RJ 2000/10414], 20 de diciembre de 2000 [RJ 2001/1861]).

De conformidad con lo que se estipulara en las Órdenes Ministeriales de 9 de septiembre de 1993 y de 9 de abril de 1999, el régimen retributivo del profesorado de religión católica era el propio del profesorado interino del mismo nivel, puesto que esa equiparación quedó expresamente establecida en la cláusula tercera de la primera de las Órdenes citadas, y en la cláusula sexta del convenio sobre régimen económico del aludido profesorado que se publicara a través de la segunda Orden mencionada. El Tribunal reprocha el uso de la técnica del «espigueo», según la cual se hace invocación aislada de la norma favorable, mas rechazando el sometimiento al bloque normativo contenido en el Convenio colectivo.

En definitiva, «la afirmación de que la ausencia de reconocimiento al colectivo en esta litis concernido del complemento de antigüedad lesiona el principio de igualdad consagrado en el artículo 14 de la Constitución, es la afirmación de una situación de desigualdad que parte de términos de comparación inadecuados: el régimen retributivo del personal laboral al servicio de la Junta que detenta la categoría de profesor o de docente y que se rige por el Convenio colectivo antes dictado, frente al bien distinto régimen retributito de los funcionarios interinos docentes y que se rige por normas relativas a la función pública. Como dijo la sentencia del Tribunal Supremo de 17 de septiembre de 2002, una comparación así propuesta es incorrecta y la misma no puede justificar la afirmación de lesividad alguna del principio constitucional de igualdad, puesto que la comparación que sí procedería sería con los funcionarios interinos docentes de bachillerato o, acaso, con los funcionarios de carrera de tal nivel educativo, pero no con el personal laboral con categoría genérica de profesor». 
- Sentencia del Tribunal Superior de Justicia de Castilla y León (Sala de lo Social), de 16 de enero de 2006 (JUR 2006/41301)

Aplica doctrina legal, con cita de la sentencia del Tribunal Supremo de 17 de mayo de 2000 (RJ 2000/5513). La negativa a la concesión del complemento de antigüedad no vulnera las cláusulas antidiscriminatorias del inciso segundo del artículo 14 de la Constitución Española y del 17.1 del Estatuto de los Trabajadores, porque no se aprecia aquí la presencia de ningún móvil discriminatorio. Y remite una vez más al erróneo término de comparación escogido por parte de los recurrentes, «pues la que procedería es con los funcionarios interinos docentes de Bachillerato o, en su caso, con los funcionarios de carrera de tal nivel educativo, pero no con el personal laboral con categoría genérica de profesor (...). Aplicando la anterior doctrina al supuesto debatido y dado que solicitan que se les aplique el artículo 15.6 del Estatuto de los Trabajadores, precepto que no les es de aplicación ya que su retribución es la correspondiente a los funcionarios interinos, se ha de desestimar este motivo de recurso».

(De la misma Sala, en idéntico sentido, Sentencias de 9 [JUR 2006/55170] y 18 de enero de 2006 [JUR 2006/54594])

\section{Cajas de Ahorros}

La batalla que sostienen determinadas las Cajas de Ahorro de fundación eclesial en defensa de su autonomía frente a lo que consideran un intervencionismo ilegítimo por parte de los gobiernos autonómicos está generando resoluciones judiciales de interés.

La Ley 5/2005, de 22 de abril, de Ordenación económica, reformó la Ley 31/1985, sobre órganos rectores de Cajas de Ahorro, de 2 de agosto, para deshacer los efectos de la modificación anterior, de 2002 (Ley 44/2002, de 22 de noviembre). Mediante la norma últimamente referida, se otorgaban competencias al Ministerio de Economía en materia de aprobación de Estatutos, de los Reglamentos que regulen la designación de miembros de los órganos de gobierno y del presupuesto anual de la Obra social de las Cajas fundadas por la Iglesia.

Las quejas relativas a la interpretación de las normas sobre presencia de representantes de la Iglesia católica en los órganos de representación de las Cajas de Ahorro ha dado lugar a las Sentencias del Tribunal Superior de Justicia de Castilla y León (Sala de lo Contencioso-Administrativo), de 4 de enero (JUR 2006/55201) y de 12 de diciembre (JUR 2007/23338).

Por su parte, la Sentencia del Tribunal Superior de Justicia de Madrid (Sala de lo Contencioso-Administrativo), de 24 de enero (JUR 2006/155599), 
se pronuncia sobre la conformidad o no a derecho de la aplicación de la Disposición Adicional $2^{\underline{a}}$ de la Ley 31/1985, modificada por la 44/2002 en el particular caso de Cajasur, fruto de una fusión entre la entidad fundada por la Iglesia y la Caja Provincial de Ahorros de Córdoba.

\section{Libertad de enseñanza}

- Sentencia del Tribunal Superior de Justicia de Madrid (Sala de lo Contencioso-Administrativo), de 24 de marzo (JUR 2006/184865)

Se impugna la liquidación del IRPF por no haber considerado la minoración de la base imponible general con el importe de los gastos de escolarización en centros de titularidad privada. No admitir la mencionada desgravación fiscal conculca la libertad de enseñanza del artículo 27 de la Constitución y en especial el derecho de los padres a elegir la formación religiosa y moral que desean para sus hijos. Sin embargo, a juicio de la Sala, no existe el derecho de los particulares a exigir al legislador el reconocimiento de exenciones $\mathrm{u}$ otros beneficios fiscales, pues razones de política económica y social sólo las justifican. Cita en su apoyo las sentencias 214/1994, de 14 de julio, y 86/1985, de 10 de julio, del Tribunal Constitucional. Según esta última, el derecho a la educación no comprende el derecho a la gratuidad educativa en cualesquiera centros privados porque los recursos públicos son limitados y no han de acudir, incondicionalmente, allá donde vayan las preferencias individuales de los contribuyentes.

Varias resoluciones judiciales se pronuncian acerca de los complementos retributivos que corresponde abonar a las Administraciones Autonómicas en cumplimiento de los conciertos educativos establecidos con los centros privados: Tribunal Superior de Justicia de Valencia (Sala de lo Social), de 31 de enero (JUR 2006/135007), sobre el complemento autonómico de homologación; Tribunal Superior de Justicia de Aragón (Sala de lo Social), de 31 de enero (JUR 2006/105603), sobre la paga extraordinaria por antigüedad; Tribunal Superior de Justicia de Extremadura (Sala de lo Social), de 23 de febrero (JUR 2006/95166), sobre el premio de antigüedad.

\section{Días festivos}

- Sentencia del Tribunal Superior de Justicia de Andalucía, Granada (Sala de lo Social), de 1 de marzo (AS 2006/1084)

El Convenio colectivo indica que los festivos se corresponden únicamente con los festivos nacionales, autonómicos y locales y en ningún caso con 
los domingos. La clara voluntad de los redactores y firmantes del Convenio impiden equiparar domingos y festivos a los solos efectos de devengo de la retribución denominada "compensación por jornada continuada», siendo evidente que si se hubiesen querido equiparar así se hubiera redactado.

\section{Seguridad Social de clérigos y religiosos}

- Sentencia del Tribunal Superior de Justicia de Madrid (Sala de lo Social), de 24 de marzo (AS 2006/1234)

No hay incompatibilidad entre la actividad sacerdotal y el cobro de las prestaciones de desempleo derivado de la pérdida de otro trabajo. «El ejercicio del sacerdocio no puede considerarse trabajo por cuenta ajena en la acepción jurídica del término ni el estipendio percibido por ello una remuneración propiamente salarial, sino un medio de subsistencia de quien se dedica a tal menester como miembro al servicio de una comunidad que provee a su necesidades más perentorias para que pueda desarrollar así su ministerio, no existiendo así una empresa empleadora en el auténtico sentido de la palabra, ni, en fin, una relación de naturaleza laboral».

- Sentencia del Tribunal Superior de Justicia de Cataluña (Sala de lo Social), de 25 de enero (JUR 2006/115973)

Si computados los períodos trabajados en el desarrollo de su actividad sacerdotal o religiosa el demandante tienen cubierto el período de carencia genérica que establece el artículo 161. 1 b) de la Ley General de Seguridad Social para el derecho a la pensión de jubilación, reúne el requisito que exige el artículo 215.1.3 de la misma Ley para el derecho al subsidio de prejubilación cuestionado.

\section{- Sentencia del Tribunal Superior de Justicia de Castilla-La Mancha} (Sala de lo Social), de 12 de enero (JUR 2006/74023)

La cuestión del abono del capital coste por parte de los sacerdotes y religiosos secularizados que acceden a la pensión de jubilación es una cuestión ya resuelta por la mayoría de los Tribunales Superiores de Justicia y por el Tribunal Supremo. Este último, en Sentencia de 26 de marzo de 2004, afirmó que el desarrollo reglamentario de la disposición adicional 10 de la Ley 13/1996, de 30 de diciembre, de Medidas Fiscales administrativas y del Orden social, llevado a cabo por los Reales Decretos 487/1998 y 2665/1998 no incurre en ultra vires, al imponer a los 
beneficiarios de la obligación de abonar el capital coste de la parte de pensión que se derive de los años de ejercicio sacerdotal o religioso que hayan sido reconocidos como cotizados a la Seguridad Social, al amparo de lo establecido por las mismas normas citadas. «En ningún momento establece la disposición, ni tampoco puede deducirse de su contenido, que la única autorización que se concedía al Gobierno era para acordar, sin el establecimiento de ninguna contraprestación, el cómputo como cotizado del expresado periodo, pues en tal caso la Ley lo hubiese dispuesto así, sin necesidad de acudir a la potestad reglamentaria del Gobierno el desarrollo normativo. La actuación reglamentaria resulta en este caso acorde con los principios de solidaridad y reparto que inspiran la regulación de las prestaciones de la Seguridad Social, para que en definitiva no implique un perjuicio para la caja del Sistema cuidando de salvar el carácter contributivo de la prestación».

No cabe extraer la conclusión de que la Ley 13/1996 pretenda establecer, para los colectivos de Sacerdotes y Religiosos de la Iglesia Católica secularizados, un nivel de protección para la jubilación que resulte discriminatorio con el que se dispensa al resto de los trabajadores incluidos en el sistema de la Seguridad Social desde el momento de su creación, pues sería contrario al principio de igualdad consagrado en el artículo 14 de la Constitución, al que están sometidas las leyes.

(En el mismo sentido, Sentencia del Tribunal Superior de Justicia de Canarias, Las Palmas [Sala de lo Social], de 21 de marzo [JUR 2006/176584])

Por otra parte, como también es sabido, el descuento practicado sobre la cantidad del capital coste por la gestión de la tramitación del expediente resulta improcedente. En tal sentido, Sentencia del Tribunal Superior de Justicia de Castilla-La Mancha (Sala de lo Social), de 6 de abril (JUR 2006/171604).

\section{Matrimonio}

- Sentencia del Tribunal Superior de Justicia de Castilla y León (Sala de lo Social), de 6 de marzo de 2006 (AS 2006/1256)

En opinión de la recurrente, la intención matrimonial que no pudo llevarse a cabo por la muerte del futuro cónyuge un día antes de la boda sería suficiente, según la normativa canónica, para constituir el matrimonio y obtener los correspondientes efectos civiles, de los que se seguiría el derecho a la pensión de viudedad. Advierte la Sala que, siendo una demanda planteada ante el órgano jurisdiccional laboral, la interpretación de las normas se hará con arreglo a la normativa estatal y no canónica. Las uniones de hecho, señala, no son equivalentes al matrimonio ni el consentimiento presunto a propósito de contraer matrimonio equivale al consentimiento formal, que constituye la médula de la institución. 


\section{AudienCIAS PROVINCIALES}

\section{Libertad religiosa}

- Sentencia Juzgado de los Contencioso-Administrativo de la Comunidad Valenciana, de 13 de febrero de 2006 (RJCA 2006/302)

Considera el Juzgado que las procesiones tienen per se naturaleza religiosa, sin que sea relevante la distinción contenida en la Resolución Municipal recurrida entre actos religiosos o tradicionales según sean cerrados o abiertos los lugares donde se celebren. En tal modo, la obligación de la presencia del funcionario - policía local — cede ante el derecho fundamental de libertad religiosa, pues el cometido llamado a desempeñar en la procesión no se refería a la seguridad ciudadana sino que se se prestaba en el marco puramente protocolario.

- Sentencia de la Audiencia Provincial de Barcelona (Penal), de 13 de enero de 2006 (JUR 2006/88657)

Constituye un delito de omisión de deberes ciudadanos, previsto y penado en el art. 143 de la Ley Orgánica 5/1985, Reguladora del Régimen electoral, la ausencia, con pleno conocimiento de haber sido designado, a la convocatoria a formar parte de la mesa electoral en su respectivo colegio. «Dicho deber cívico, aparece como inexcusable salvo causas de fuerza mayor, razón por la que incluso el Tribunal Constitucional ha denegado el derecho de objeción de conciencia a aquellos miembros de la comunidad que no desean participar en la convocatoria electoral, distinguiendo claramente el derecho personal inalienable a no participar en las elecciones mediante la no emisión de voto y el deber de colaborar en su normal desarrollo».

\section{Matrimonio}

- Sentencia de la Audiencia Provincial de Madrid (Civil), de 23 de marzo de 2006 (JUR 2006/151185)

El suplico del escrito de recurso pide declaración de que la sentencia canónica de nulidad, cuyos efectos civiles fueron reconocidos, se revoque, por no ser ajustada al derecho del Estado. En efecto, la citada sentencia se basaba sobre la inmadurez, «que no se recoge entre las causas de nulidad que se contemplan en el Código Civil español, que considera suficiente la mera capacidad de entender y querer (capacidad natural) para reputar válidamente prestado el 
consentimiento matrimonial, partiendo en todo caso de la presunción general de capacidad de todos los mayores de edad para los actos de la vida civil (art. 322 CC), y de la consideración del ius nubendi como derecho fundamental de la persona reconocido en el artículo 32 de la Constitución Española».

No puede dejar de recordarse el principio general según el cual no se reciben resoluciones dictadas por autoridades que supongan vulneración de los requisitos esenciales, por formar parte del orden público del foro. Sin embargo, en la concreta materia a la que ahora nos referimos, hay una doctrina consolidada - véase por todas Sentencia del tribunal Supremo de 23 de noviembre de 1995 (RJ 1995/8433) — según la cual «la homologación de las sentencias dictadas por los tribunales eclesiásticos no autoriza a la revisión, en el proceso civil, de las causas canónicas de nulidad, ya que el repetido ajuste al derecho del Estado se produce por la mera concurrencia de las condiciones formales para el reconocimiento de las sentencias extranjeras, con el plus que representa su no contradicción con los principios jurídicos públicos y privados de nuestro ordenamiento del Estado». En relación con el caso planteado, la Sala concluye que la sentencia canónica es perfectamente ajustada a la legalidad estatal, «entendiendo que este ajuste no solo se produce entre la causa estimada y la que contempla el artículo 73, en el sentido de que la incapacidad psíquica para cumplir las obligaciones esenciales del matrimonio aparece vinculada al consentimiento matrimonial, en aras a la comprensión y asunción por ambas partes del contenido del vínculo matrimonial, sino que no quedan afectados principios fundamentales recogidos en nuestro ordenamiento, como pudiera acontecer en supuestos de estimación de la nulidad por motivos o razones exclusivamente religiosas, dada la aconfesionalidad del Estado Español».

\section{Cementerios}

- Sentencia de la Audiencia Provincial de Pontevedra (Civil), de 5 de mayo de 2006 (JUR 2006/158694)

El recurso de apelación se funda sobre la falta de legitimación activa de los actores ad processum al carecer de título adquisitivo de la sepultura sobre la que versa el pleito. Con tal motivo, el magistrado razona acerca del régimen jurídico de los cementerios parroquiales de la Iglesia católica que, en principio, «no se rigen por normas civiles sino por las disposiciones de Derecho Canónico, de acuerdo con lo previsto en las normas concordantes entre la Santa Sede y el Estado Español, de tal modo que la administración y el gobierno de los cementerios parroquiales o campos santos incumbe exclusivamente a la Iglesia y 
especialmente al ordinario del lugar, que los cementerios una vez bendecidos son cosas sagradas que quedan fuera del comercio de los hombres, de tal modo que, para la concesión de terrenos en los mismos a sepultura o panteón particular se hace precisa siempre la licencia del ordinario previo expediente y pago de la tasa correspondiente (Canon 1209.1 y Constitución Sinodal no 1063) por lo que no se podrán transmitir ni enajenar sin aprobación expresa de la Iglesia Católica». Añade, sin embargo, la cita del Cánon 1290, según el cual «lo que en cada territorio establece el derecho civil sobre los contratos, tanto en general como en particular, y sobre los pagos, debe observarse con los mismos efectos en virtud del derecho canónico en materias sometidas a la potestad de régimen de la Iglesia, salvo que sea contrario a derecho divino o que el derecho canónico prescriba otra cosa».

Documentada la primera transmisión del dominio de los nichos a la Iglesia - concluye-, nada impide la virtualidad de las normas civiles sobre transmisión de bienes sobre lo adquirido: «no puede obviarse la virtualidad de las transmisiones civiles ulteriores a la adquisición de la propiedad de los nichos, ni sujetarse ésta a la aprobación de la Iglesia, pues el canon citado supra remite a las normas de derecho común, y el mismo demandado parte de su título hereditario derivativo, centrando su impugnación de la sentencia en la nulidad de la transmisión que, vía donación verbal, entiende se les ha reconocido a los actores».

- Sentencia de la Audiencia Provincial de Segovia (Penal), de 9 de enero de 2006 (JUR 2006/55180)

No se estima posible trasladar sin más la responsabilidad administrativa o dominical que se deriva del Concordato y disposiciones canónicas respecto de la administración y cuidado de los cementerios parroquiales, al ámbito penal, y con esa sola base exigir responsabilidad criminal alguna, como consecuencia de las lesiones sufridas por la recurrente. Todo ello sin perjuicio de las acciones civiles que puedan ser ejercitadas en la vía correspondiente.

\section{Responsabilidad civil subsidiaria}

- Sentencia de la Audiencia Provincial de Madrid (Penal), de11 de octubre de 2006 (JUR 2006/255986)

El número tercero del art. 120 del Código Penal predica la responsabilidad civil subsidiaria de las «personas naturales o jurídicas, en los casos de delitos o faltas cometidos en las establecimientos de los que sean titulares, cuando 
por parte de los que los dirijan o administren, o sus dependientes o empleados, se hayan infringidos los reglamentos de policía o las disposiciones de la autoridad que estén relacionados con el hecho punible cometido, de modo que éste no se hubiera producido sin dicha infracción». Tal precepto, para su aplicación requiere que las personas naturales o jurídicas: a) sean titulares de las establecimientos en los que los delitos o faltas se comentan; b) que las personas que las dirijan a administren a sus dependientes o empleados hayan infringido reglamentos de policía o disposiciones de la autoridad. La infracción podrá ser tanto por acción como por omisión y las normas que sean infringidas pueden haber adoptado tanto la forma general como la más especial y concreta de simple disposición adoptada por quien sea autoridad; c) esas disposiciones de la autoridad es preciso que tengan con el hecho punible una relación tal que sin su infracción el hecho no se hubiera producido.

Ante un caso de condena de secretario de Vicaría como autor de de un delito continuado de abusos sexuales lo trascendente será, a efectos indemnizatorios, «que el Obispado tenga dicha personalidad jurídica como aptitud para soportar un pronunciamiento civil condenatorio, una vez cumplidos los demás requisitos, lo que sucede en el caso de autos, pues la actuación del acusado debió ser vigilada por el Arzobispado, de acuerdo con los tradicionales criterios empleados por nuestro más alto Tribunal en materia de responsabilidad civil subsidiaria, que se fundamenten en la "culpa in eligendo" y en la "culpa in vigilando" como ejes sustanciales de dicha responsabilidad civil. Todo ello de acuerdo con lo solicitado por el ministerio Fiscal, pues el acusado, como secretario de la Vicaría, dependía del Arzobispado, y llevó a efecto su conducta en las dependencias de dicha Vicaría».

\section{Entidades eclesiásticas}

- Sentencia de la Audiencia Provincial de Pontevedra (Civil), de 7 de septiembre de 2006 (JUR 2006/252153)

Impugna la compañía aseguradora la reclamación formulada por la diócesis de indemnización por daños sufridos en templo parroquial. Invoca, en primer lugar, la imposibilidad por parte del párroco de actuar en nombre de la diócesis, cuya representación ostenta el ecónomo del obispado; y, además, que la contratante de la póliza de seguro ha sido la parroquia, que dispone de personalidad jurídica propia, a través del párroco en cuanto representante de la misma, siendo por lo tanto la parroquia la legitimada para formular la reclamación por los daños producidos. 
La primera objeción queda desvirtuada a la vista de la autorización concedida al párroco por el vicario general de la diócesis, obrante en autos, para que, en representación de la referida diócesis, pudiere actuar en la demanda contra la aseguradora demandada, otorgándole al efecto, hasta la resolución de la causa, todas las habilitaciones y facultades necesarias según la normativa legal, lo que permitió al párroco otorgar el oportuno poder de representación para entablar la demanda, y, subsiguientemente, promoverla en nombre de la diócesis.

Siendo asimismo merecedora de rechazo la segunda objeción, toda vez que, al ser el templo parroquial afectado un bien propiedad de la Iglesia, hay que entender que la diócesis (a quien pertenece la parroquia en cuestión) se encuentra legitimada para reclamar la correspondiente indemnización, en calidad de implícito beneficiario, pudiendo subrogarse en la posición de la parroquia asegurada en el contrato de seguro, de forma análoga a la contemplada en el art. 34 de la LCS. Corroborando lo anterior el hecho de que la reclamación judicial por el párroco, en nombre de la parroquia, venga a requerir la autorización por escrito del Obispado, lo que en último término deja en manos del mismo la decisión de promover el litigio. Pudiendo igualmente apuntarse, como dato significativo, la manifestación del Sr. ecónomo del Obispado, en el acto del juicio, en el sentido de haberse preocupado de que la póliza de seguro multirriesgo fuese suscrita por las parroquias de la diócesis.

- Auto del Juzgado de lo Mercantil de Granada (Civil), de11 de abril de 2006 (AC 2006/476)

Asociación religiosa solicita medidas cautelares para impedir el desfile procesional de otra entidad, invocando, al amparo de la legislación de marcas, la titularidad registral del nombre y emblema que pretende utilizar. Se inadmite la solicitud. No cabe descartar, por las peculiares dificultades constatadas en el desarrollo de la vida de la asociación, un registro de mala fe, ni se aprecian las razones de urgencia alegadas. Es de interés reproducir en este lugar, por su originalidad y brillantez, uno de los párrafos del Auto: «Desconocemos, no se indica, a qué género de actividad empresarial o mercantil se dedica la actora, y menos aún a qué sector del mercado se dirigen sus productos o servicios, y cuáles son. En este punto no debemos olvidar, salvo que nos enfrentemos ante un registro nulo, artículo 5.1 a), en relación con el artículo 51.1, ambos de la Ley de Marcas, que, como establece, el artículo 4.1, la marca sirve para distinguir en el mercado, productos o servicios de una empresa de los de otra. Tampoco se expresa quiénes son los "consumidores" destinatarios de los productos o servicios, 
que concurren en el mercado. La demandante habla de un daño gravísimo a los titulares de la marca, si se usa el nombre Cofradía Universitaria de Granada y los emblemas registrados, en un acto religioso, programado, durante años, en la misma fecha, y cuyo fin se sitúa por la actora, en la búsqueda de notoriedad y repercusión pública. Obviamente no especifica y concreta tal daño, por el desarrollo del acto, donde desde luego no podemos admitir, sin justificación alguna, y menos aún presumir, que el mismo, desarrollado como expresión de uno de los valores fundamentales de nuestro ordenamiento jurídico, la libertad de cultos y la tolerancia religiosa, se celebre sin embargo con fines publicitarios mercantiles, para introducir determinados productos y servicios en el mercado, en todo caso no identificados. Desde luego no podemos tampoco admitir, que exista un hipotético mercado de procesiones o servicios religiosos de Semana Santa, y menos aún que en él concurran empresas, donde sea necesario distinguir productos o servicios de los de sus competidores. Por tanto no se ha justificado el periculum in mora». 